\title{
Synthesis, Characterization, and Application of Novel Ni-P-Carbon Nitride Nanocomposites
}

\author{
Eman M. Fayyad ${ }^{1,+}$, Aboubakr M. Abdullah 1,*, Mohammad K. Hassan ${ }^{1}$ (D), \\ Adel M. Mohamed ${ }^{2}$ (D) , Chuhong Wang ${ }^{3}$, George Jarjoura ${ }^{3}$ and Zoheir Farhat ${ }^{3}$ \\ 1 Center for Advanced Materials, Qatar University, Doha 2713, Qatar; emfayad@qu.edu.qa (E.M.F.); \\ mohamed.hassan@qu.edu.qa (M.K.H.) \\ 2 Department of Metallurgical and Materials Engineering, Faculty of Petroleum and Mining Engineering, \\ Suez University, Suez 43721, Egypt; adel.mohamed25@yahoo.com \\ 3 Department of Mechanical Engineering, Dalhousie University, Halifax, NS B3J 2X4, Canada; \\ iriswang@dal.ca (C.W.); George.Jarjoura@dal.ca (G.J.); Zoheir.Farhat@Dal.Ca (Z.F.) \\ * Correspondence: bakr@qu.edu.qa; Tel.: +974-3307-0591; Fax: +974-4403-3889 \\ † Permanent address: Physical Chemistry Department, National Research Center, Dokki, Giza 12622, Egypt.
}

Received: 28 November 2017; Accepted: 15 January 2018; Published: 17 January 2018

\begin{abstract}
Dispersion of $2 \mathrm{D}$ carbon nitride $\left(\mathrm{C}_{3} \mathrm{~N}_{4}\right)$ nanosheets into a nickel phosphorous (NiP) matrix was successfully achieved by ultrasonication during the electroless plating of NiP from an acidic bath. The morphology and thickness, elemental analysis, phases, roughness, and wettability for as-plated and heat-treated nanocomposite were determined by scanning electron microscopy, energy-dispersive $\mathrm{X}$-ray spectroscopy, $\mathrm{X}$-ray diffraction, atomic force microscopy, and contact angle measurements, respectively. $\mathrm{C}_{3} \mathrm{~N}_{4}$ showed a homogeneous distribution morphology in the nanocomposite that changed from amorphous in case of the $\mathrm{NiP}$ to a mixed crystalline-amorphous structure in the NiP- $\mathrm{C}_{3} \mathrm{~N}_{4}$ nanocomposite. The microhardness and corrosion resistance of the as-plated nanocomposite and the heat-treated nanocomposite coating were significantly enhanced compared to the Ni-P. The nanocomposite showed a superior corrosion protection efficiency of $\sim 95 \%$, as observed from the electrochemical impedance spectroscopy (EIS) measurements. On the other hand, the microhardness of the nanocomposite was significantly increased from 780 to reach $1175 \mathrm{HV}_{200}$ for $\mathrm{NiP}$ and $\mathrm{NiP}-\mathrm{C}_{3} \mathrm{~N}_{4}$, respectively.
\end{abstract}

Keywords: electroless NiP alloy; carbon nitride; composites coating; corrosion; microhardness

\section{Introduction}

Enhancing the corrosion protection for oil and gas pipelines continues to motivate intensive research efforts to find new coatings or modify the existing ones. Electroless deposited NiP coatings, obtained by an autocatalytic process, are characterized by a combination of many unique properties such as good wear and corrosion protection efficiency, uniformity of coating thickness, and a higher hardness [1]. These properties opened the field for NiP to be used in different industries [2]. However, to improve these properties, the incorporation of nanoparticles in the NiP matrix has been tried extensively recently [3-8]. The performance of the co-deposition of hard second-phase nanoparticles such as $\mathrm{Al}_{2} \mathrm{O}_{3}, \mathrm{TiN}, \mathrm{B}_{4} \mathrm{C}, \mathrm{ZrO}_{2}, \mathrm{SiC}, \mathrm{TiO}_{2}, \mathrm{CNT}$, graphite, and diamond [9-17] with the Ni-P matrix was investigated, and has shown an enhancement in terms of microhardness, as well as corrosion and wear resistances. Nevertheless, the Ni-P matrix with the insertion of the carbon nitride $\left(\mathrm{C}_{3} \mathrm{~N}_{4}\right)$ nano-sheets has not been reported. The prediction of the possible existence of the $\mathrm{C}_{3} \mathrm{~N}_{4}$ compound is credited to Cohen and Liu $[18,19]$. Due to its high hardness and excellent thermal and chemical stability, $\mathrm{C}_{3} \mathrm{~N}_{4}$ has attracted significant interest. $\mathrm{C}_{3} \mathrm{~N}_{4}$ properties are essentially the same as those of diamond [20], i.e., the mechanical and tribological characteristics, as well as the corrosion resistance of 
its composite coatings, are expected to be excellent [21]. The goal of the present study is to prepare a new $\mathrm{NiP}-\mathrm{C}_{3} \mathrm{~N}_{4}$ nanocomposite with better corrosion resistance and mechanical properties through the incorporation of $2 \mathrm{D} \mathrm{C}_{3} \mathrm{~N}_{4}$ nanosheets during the electroless deposition of the $\mathrm{NiP}$ alloy. In addition, a comparative study between the new nanocomposite and the original $\mathrm{C}_{3} \mathrm{~N}_{4}$-free alloy will be carried out to show the superior performance of the electroless deposited $\mathrm{NiP}_{-} \mathrm{C}_{3} \mathrm{~N}_{4}$ nanocomposite compared to the NiP alloys.

\section{Experimental}

\subsection{Materials, Solutions, and Preparation}

Electroless NiP and NiP- $\mathrm{C}_{3} \mathrm{~N}_{4}$ nanocomposite coatings were deposited on an API X120 C-steel that was starting to be used recently in the oil and gas industry. The chemical composition (in wt \%) of the API X120 steel that purchased from Tianjin Tiangang Guanye Co., Ltd., (Tianjin, China) is shown in Table 1.

Table 1. The chemical composition (in wt \%) of the substrate.

\begin{tabular}{ccccccccc}
\hline $\mathbf{C}$ & $\mathbf{S i}$ & $\mathbf{M n}$ & $\mathbf{N i}$ & $\mathbf{C r}$ & $\mathbf{M o}$ & $\mathbf{C u}$ & $\mathbf{V}$ & $\mathbf{F e}$ \\
\hline 0.129 & 0.101 & 0.541 & 0.017 & 0.039 & 0.0013 & 0.015 & 0.25 & balance \\
\hline
\end{tabular}

Prior to the electroless deposition, the specimens were grinded with different grits of emery paper up to 2000, then polished with micro-polish alumina suspension ( 1 and $3 \mu \mathrm{m})$ to obtain a mirror finishing surface. After that degreasing the specimens in ultrasonicated acetone bath for $15 \mathrm{~min}$ was done, followed by alkaline cleaning for $5 \mathrm{~min}$ at $80^{\circ} \mathrm{C}$ then electro-alkaline cleaning for $2 \mathrm{~min}$ at $70{ }^{\circ} \mathrm{C}$ with $I=2 \mathrm{~A} \cdot \mathrm{cm}^{-2}$ and acid etching in $15 \mathrm{wt} \% \mathrm{H}_{2} \mathrm{SO}_{4}$ solution for $20 \mathrm{~s}$. The used alkaline cleaning solution consists of $50 \mathrm{~g} \cdot \mathrm{L}^{-1} \mathrm{NaOH}, 30 \mathrm{~g} \cdot \mathrm{L}^{-1} \mathrm{Na}_{2} \mathrm{CO}_{3}$ and $30 \mathrm{~g} \cdot \mathrm{L}^{-1} \mathrm{Na}_{3} \mathrm{PO}_{4}$ while that used in electro-alkaline cleaning consists of $15 \mathrm{~g} \cdot \mathrm{L}^{-1} \mathrm{NaOH}, 25 \mathrm{~g} \cdot \mathrm{L}^{-1} \mathrm{Na}_{2} \mathrm{CO}_{3}$ and $25 \mathrm{~g} \cdot \mathrm{L}^{-1} \mathrm{Na}_{3} \mathrm{PO}_{4}$.

After each of the pretreatment steps, the specimens were washed with deionized water. Pretreated substrate coupons of $20 \times 30 \times 10 \mathrm{~mm}^{3}$ were used in the electroless deposition process. All used solutions are analytical-grade reagents from Sigma-Aldrich (St. Louis, MO, USA).

The electroless bath for the NiP coating contained $15 \mathrm{~g} \cdot \mathrm{L}^{-1} \mathrm{NiSO}_{4} \cdot 6 \mathrm{H}_{2} \mathrm{O}, 30 \mathrm{~g} \cdot \mathrm{L}^{-1}$ $\mathrm{NaH}_{2} \mathrm{PO}_{2} \cdot \mathrm{H}_{2} \mathrm{O}, 20 \mathrm{~g} \cdot \mathrm{L}^{-1}$ lactic acid, $20 \mathrm{~g} \cdot \mathrm{L}^{-1}$ citric acid, and $0.002 \mathrm{~g} \cdot \mathrm{L}^{-1}$ thiourea, while the electroless $\mathrm{NiP}_{-} \mathrm{C}_{3} \mathrm{~N}_{4}$ nanocomposite coating bath contained $15 \mathrm{~g} \cdot \mathrm{L}^{-1} \mathrm{NiSO}_{4} \cdot 6 \mathrm{H}_{2} \mathrm{O}, 30 \mathrm{~g} \cdot \mathrm{L}^{-1}$ $\mathrm{NaH}_{2} \mathrm{PO}_{2} \cdot \mathrm{H}_{2} \mathrm{O}, 15 \mathrm{~g} \cdot \mathrm{L}^{-1}$ ammonium chloride, $30 \mathrm{~g} \cdot \mathrm{L}^{-1}$ sodium citrate, and $0.002 \mathrm{~g} \cdot \mathrm{L}^{-1}$ thiourea. $\mathrm{NaOH}$ was used to adjust the $\mathrm{pH}$ of the $\mathrm{NiP}$ and $\mathrm{NiP}-\mathrm{C}_{3} \mathrm{~N}_{4}$ plating baths to 4.5 and 8 , respectively. The two baths were maintained at $85{ }^{\circ} \mathrm{C}$. To obtain well-suspended $\mathrm{C}_{3} \mathrm{~N}_{4}$ nanosheets, which are synthesized and characterized in our previous work [22], in the electroless bath, $0.5 \mathrm{~g}$ of $\mathrm{C}_{3} \mathrm{~N}_{4}$ was added to a $100 \mathrm{~mL}$ of the plating solution that includes also $0.02 \mathrm{~g} \cdot \mathrm{L}^{-1}$ of sodium dodecyl sulfate as the surfactant. Then, the solution was mixed with ultrasonic probe for $2 \mathrm{~h}$. Finally, the mixture was poured into the original plating bath stirred at $300 \mathrm{rpm}$ using a magnetic stirrer. The coupons were immersed in the bath and the plating process lasted for $2 \mathrm{~h}$. Then, the coupons were removed from the bath, rinsed with deionized water, and dried with blowing air. After plating, three samples of each coat underwent heat treatment (HT) at $400{ }^{\circ} \mathrm{C}$ for $1 \mathrm{~h}$ under vacuum to study the change in the properties of the $\mathrm{NiP}$ and $\mathrm{NiP}-\mathrm{C}_{3} \mathrm{~N}_{4}$ nanocomposite after the HT.

\subsection{Characterization}

The surface morphology and the elemental analysis of the nanocomposite were performed using a scanning electron microscope (SEM, Nova NanoSEM 450, Thermo Fisher Scientific, Eindhoven, The Netherlands) coupled with an energy-dispersive X-ray spectroscopy (EDX, Bruker detector $127 \mathrm{eV}$, Bruker, Leiderdorp, The Netherlands). The analysis of the different phases of the nanocomposite coating was performed using X-ray diffractometry (XRD, Miniflex2 Desktop, $\mathrm{Cu} K \alpha$, 
Rigaku, Tokyo, Japan). A Vickers microhardness tester (FM-ARS9000, Future-Tech Corp., Tokyo, Japan) was used to measure the microhardness at a load of $200 \mathrm{~g}$ for $10 \mathrm{~s}$. The measurements were repeated five times on each sample and the mean of the results was considered. Atomic Force Microscopy (AFM) was used to inspect the heterogeneities (surface roughness) of the coated specimens. An MFP3D Asylum research (Asylum Research, Santa Barbara, CA, USA) AFM equipped with a silicon probe (Al reflex coated Veeco model-OLTESPA, Olympus, Tokyo, Japan; Spring constant: $2 \mathrm{~N} \cdot \mathrm{m}^{-1}$, resonant frequency: $70 \mathrm{kHz}$ ) was utilized for all roughness experiments. Measurements were conducted at ambient conditions using the Standard Topography AC in air (tapping mode in air). Contact angle measurements were conducted using a DataPhysics OCA35, DataPhysics Instruments GmbH, Filderstadt, Germany). Four microliters of deionized water were used as the probing liquid. To achieve accurate results, at least five contact angles were measured, and their average is reported.

\subsection{Corrosion Study}

The electrochemical impedance spectroscopy (EIS) was performed using a three-electrode cell at $25{ }^{\circ} \mathrm{C}$ in a $3.5 \%(w / w) \mathrm{NaCl}$ solution utilizing a Gamry electrochemical workstation (Gamry Instruments, Warminster, PA, USA). The corrosion resistance of the electroless-plated NiP and the NiP- $\mathrm{C}_{3} \mathrm{~N}_{4}$ nanocomposite was examined. An area of $2 \mathrm{~cm}^{2}$ of the coated specimen was the working electrode, while an $\mathrm{Ag} / \mathrm{AgCl}$ electrode and a graphite rod were used as the reference and the counter electrodes, respectively. A $10 \mathrm{mV}$ AC amplitude was used, and the frequency varied from $0.01 \mathrm{~Hz}$ to $100 \mathrm{kHz}$. All EIS data were recorded after a steady-state, open-circuit potential was achieved. A $3.5 \mathrm{wt} \%$ sodium chloride solution was utilized to expose a $2 \mathrm{~cm}^{2}$ area of the surface. Following the immersion of the specimens in a $3.5 \%(w / w) ~ \mathrm{NaCl}$ solution for $3 \mathrm{~h}$ and keeping them at an open-circuit potential for $20 \mathrm{~min}$, potentiodynamic polarization tests (Tafel analysis) were performed. A scan rate of $0.167 \mathrm{mV} \cdot \mathrm{s}^{-1}$ and a potential range of $\pm 250 \mathrm{mV}$ vs. the open circuit potential was used to acquire the anodic and cathodic polarization curves.

\section{Results and Discussion}

\subsection{Surface Morphology of the Ni-P and Ni-P-C $\mathrm{C}_{3} \mathrm{~N}_{4}$ Coatings}

The SEM surface morphology of the as-plated $\mathrm{NiP}$ and $\mathrm{NiP}-\mathrm{C}_{3} \mathrm{~N}_{4}$ nanocomposite layers are represented in Figure 1a,b, respectively. The surfaces of both coatings exhibit a typical "cauliflower-like" morphology that shows many grains, and each contains many fine granules. Although the cauliflower morphology is a common feature for the electroless-plated NiP alloys, it can be observed that there are spaces between the nodules that facilitate the diffusion of the corrosive media to the substrate, as shown in Figure 1a. Figure $1 \mathrm{~b}$ reveals a fine microstructure of the $\mathrm{NiP}-\mathrm{C}_{3} \mathrm{~N}_{4}$ nanocomposite coating compared to the NiP coatings that are shown in Figure 1a. This may be attributed to the uniform distribution of the $\mathrm{C}_{3} \mathrm{~N}_{4}$ nanosheets in the NiP composite coating surface that results in a more fine compact structure with higher surface roughness, as shown later in AFM measurements. Figure 1c, $\mathrm{d}$ showed the EDX spectra of the as-plated NiP and NiP- $\mathrm{C}_{3} \mathrm{~N}_{4}$ coatings that illustrate the presence of nitrogen in the nanocomposite, which proved the successful co-deposition of the $\mathrm{C}_{3} \mathrm{~N}_{4}$ nanosheets into the NiP matrix. As seen in Figure 1e, for more illustration, the EDX mapping proves that the $C_{3} N_{4}$ nanosheets are uniformly and homogeneously distributed in the NiP matrix.

Furthermore, examination of Figure $1 \mathrm{c}, \mathrm{d}$ shows that the $\mathrm{NiP}$ and $\mathrm{NiP}-\mathrm{C}_{3} \mathrm{~N}_{4}$ coatings contain approximately 10.48 and $8.76 \mathrm{wt} \%$ phosphorus, respectively. According to [23,24], the microstructure of ENP (Electroless NiP) coatings has been reported to be either amorphous or crystalline, or both, depending on the phosphorous content involved. For instance, crystalline, mixed amorphous-crystalline, and amorphous structures have been reported for low (1-5 wt \%), medium (6-9 wt \%), and high (10-13 wt \%) phosphorous ENP coatings, respectively. Therefore, the microstructure of the NiP coating is amorphous (see XRD results in Section 3.3), whereas that 
of the NiP- $\mathrm{C}_{3} \mathrm{~N}_{4}$ coating tends to be a mixed crystalline-amorphous, as depicted by XRD results in Section 3.3.

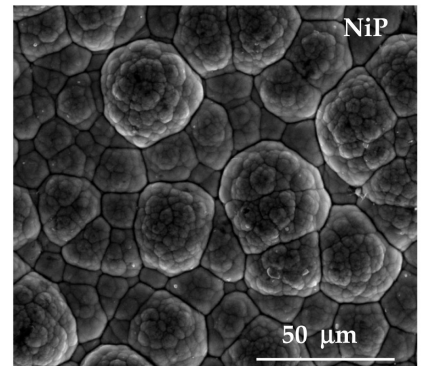

(a)

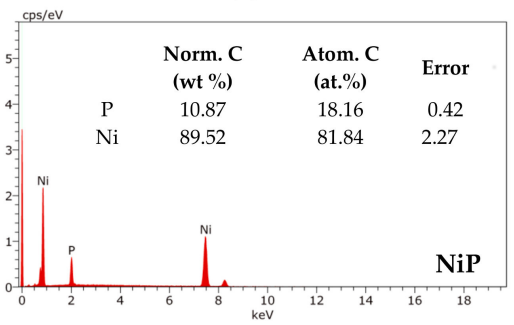

(c)

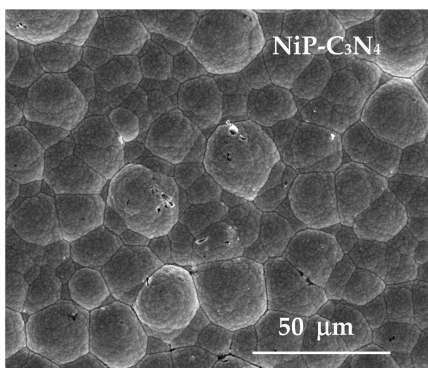

(b)

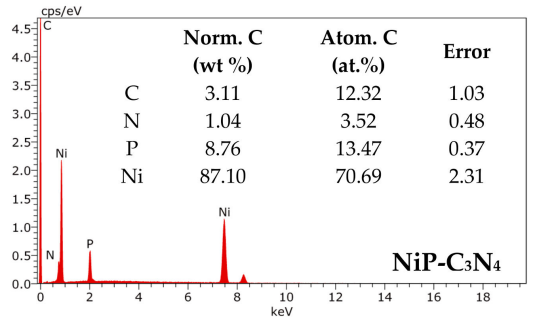

(d)

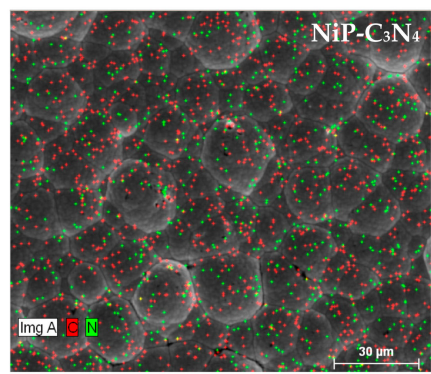

(e)

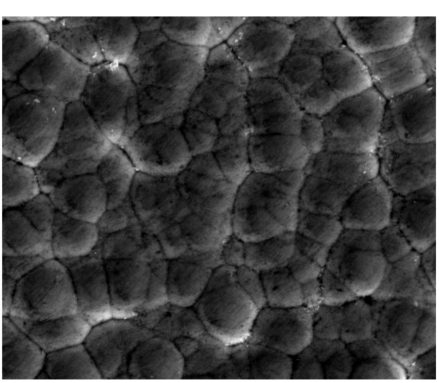

(f)

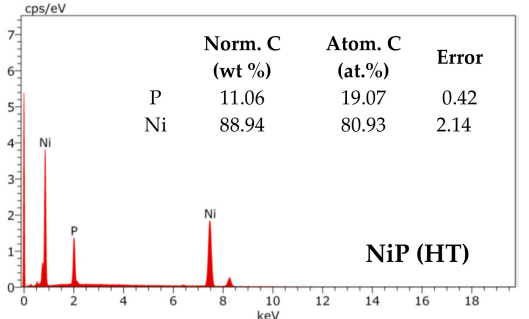

(h)

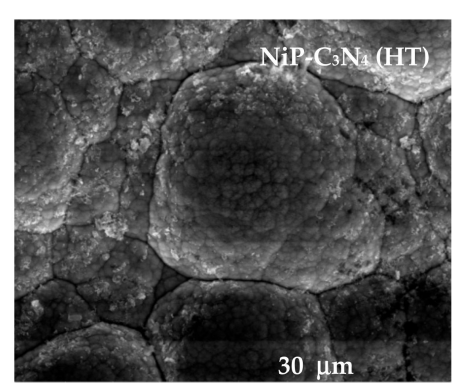

(g)

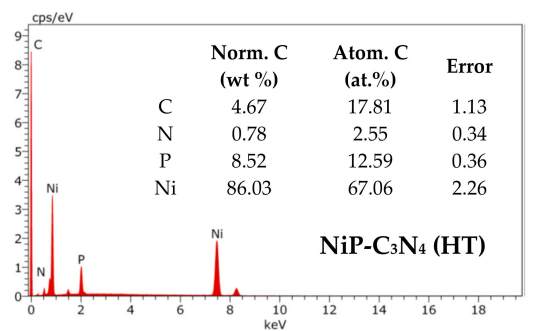

(i)

Figure 1. (a,b,f,g) SEM micrographs and (c, d,h,i) EDX elemental analysis of the electroless as-plated $(\mathbf{a}, \mathbf{c}) \mathrm{NiP},(\mathbf{b}, \mathbf{d})$ as-plated $\mathrm{NiP}-\mathrm{C}_{3} \mathrm{~N}_{4},(\mathbf{f}, \mathbf{h})$ heat-treated $\mathrm{NiP}$, and $(\mathbf{g}, \mathbf{i})$ heat-treated $\mathrm{NiP}-\mathrm{C}_{3} \mathrm{~N}_{4}$, respectively; (e) EDX mapping for the $\mathrm{C}$ and $\mathrm{N}$ elements on the surface of the $\mathrm{NiP}-\mathrm{C}_{3} \mathrm{~N}_{4}$ composite coating.

After $\mathrm{HT}$ at $400{ }^{\circ} \mathrm{C}$ for $1 \mathrm{~h}$, the granular morphology of the as-plated NiP coating is gradually diminished and becomes smoother, as shown in Figure 1f. Comparison of the as-plated $\mathrm{NiP}_{-} \mathrm{C}_{3} \mathrm{~N}_{4}$ 
composite coating to the heat-treated composite coating reveals that there is a difference in the nodular morphology, and the particles become larger and more agglomerated, as shown in Figure 1g. The change in the morphology with HT may be attributed to the different diffusion coefficients for the different phases in the composite coatings.

The cross-section morphology of as-plated $\mathrm{NiP}$ and NiP- $\mathrm{C}_{3} \mathrm{~N}_{4}$ coatings was checked using SEM, as shown in Figure 2. It was revealed that the thickness of the NiP coating is approximately $52 \mu \mathrm{m}$, whereas the NiP- $\mathrm{C}_{3} \mathrm{~N}_{4}$ coating has a thickness of $35 \mu \mathrm{m}$. This indicates that the existence of the reinforcing phase $\left(\mathrm{C}_{3} \mathrm{~N}_{4}\right)$ in the coating decreased the thickness considerably. Decreasing the thickness reveals the low deposition rate of the $\mathrm{NiP}-\mathrm{C}_{3} \mathrm{~N}_{4}$ coating compared to that for the NiP one. This may be attributed to the possibility of the physical adsorption of some $\mathrm{C}_{3} \mathrm{~N}_{4}$ particles on the catalytic surface that result in the minimization of the available active sites for the deposition process that decreases the overall deposition rate [25]. In addition, there are no defects or cracks observed at the substrate-coating interface. This demonstrates the good adhesion of the coatings. The thickness of both coatings does not change after the HT.

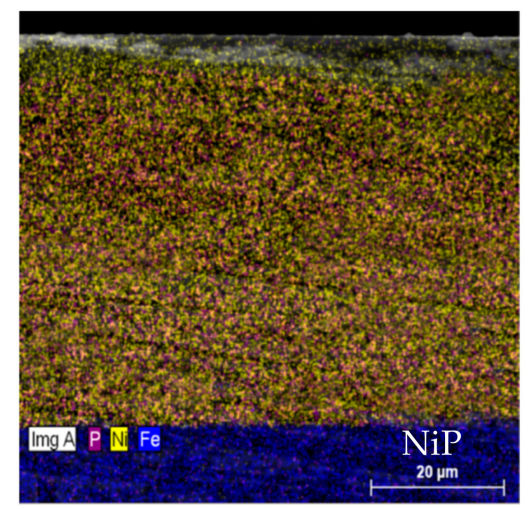

(a)

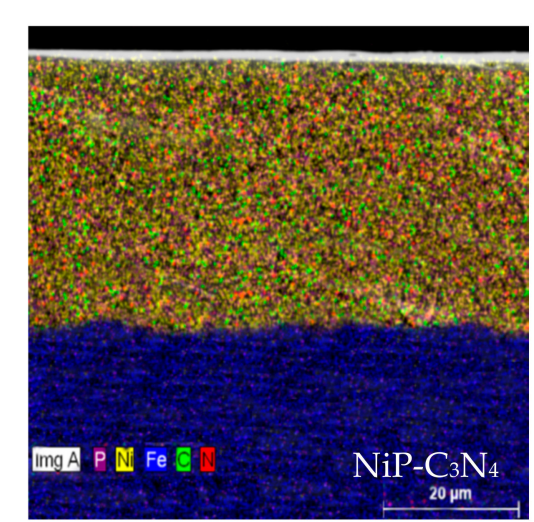

(b)

Figure 2. The cross-sectional SEM-photomicrographs of the (a) $\mathrm{Ni}-\mathrm{P}$ and (b) $\mathrm{NiP}-\mathrm{C}_{3} \mathrm{~N}_{4}$ nanocomposite coatings.

\subsection{Structures of the Ni-P and Ni-P-C $\mathrm{C}_{3} \mathrm{~N}_{4}$ Coatings}

XRD patterns of both as-plated and heat-treated Ni-P and Ni-P- $\mathrm{C}_{3} \mathrm{~N}_{4}$ layers are represented in Figure $3 a, b$, respectively. It is observed that the diffraction pattern of both $\mathrm{NiP}$ and $\mathrm{NiP}-\mathrm{C}_{3} \mathrm{~N}_{4}$ composite coatings before the HT has only a single broad peak at $44.5^{\circ}$, which is related to a face-centered cubic (FCC) $\mathrm{Ni}$ (111) plane, as shown in Figure 3a. The peaks representing the $\mathrm{C}_{3} \mathrm{~N}_{4}$ particles that appear in the inset of Figure $3 \mathrm{a}$ are not detected in the diffraction pattern of the composite coating shown in Figure 3a. This may be attributed to the low quantity of $\mathrm{C}_{3} \mathrm{~N}_{4}$ and high density of Ni diffraction peaks. According to the EDX results, the NiP- $\mathrm{C}_{3} \mathrm{~N}_{4}$ composite coating microstructure is a mixture of amorphous and crystalline phases. Based on the full width at half maximum (FWHM), it is found that the FWHM of the NiP and NiP- $\mathrm{C}_{3} \mathrm{~N}_{4}$ composite coatings is 7.63 and 6.34, respectively. Therefore, it is concluded that the presence of $\mathrm{C}_{3} \mathrm{~N}_{4}$ in the coating promotes the formation of crystalline phase; see a similar case in Ref. [26].

After $\mathrm{HT}$, the as-plated $\mathrm{NiP}$ coating crystallized mainly as $\mathrm{Ni}_{3} \mathrm{P}$ particles on the surface. As the amorphous structure is metastable, its peak decreased after $\mathrm{HT}$ and crystalline $\mathrm{Ni}$; also, $\mathrm{Ni}_{3} \mathrm{P}$ phases are formed. It is clear that the diffraction pattern of the $\mathrm{C}_{3} \mathrm{~N}_{4}$ nanocomposite coating coincides with that of the NiP coating, i.e., the presence of $\mathrm{C}_{3} \mathrm{~N}_{4}$ nanosheets in the coating has not affected the phase angle (peaks positions) of the coating, and new peaks have not appeared. Moreover, it can be observed that the intensity of the resulted peaks decreases dramatically for the $\mathrm{NiP}-\mathrm{C}_{3} \mathrm{~N}_{4}$ nanocomposite coating compared to $\mathrm{C}_{3} \mathrm{~N}_{4}$-free one. This can explained by the decrease in the amount of deposited $\mathrm{Ni}$ and $\mathrm{P}$ as a result of presence of $\mathrm{C}_{3} \mathrm{~N}_{4}$ in the coating. This is illustrated in the EDX charts shown above in Figure 1h,i, in which the Ni and P contents decreased by $3.2 \mathrm{wt} \%$ and $22.9 \mathrm{wt} \%$, respectively. 
In addition, as illustrated in Figure $1 \mathrm{~h}$, increasing the $\mathrm{P}(\mathrm{wt} \%)$ in the heat-treated $\mathrm{NiP}$ coating results in smaller Ni diffraction peaks.

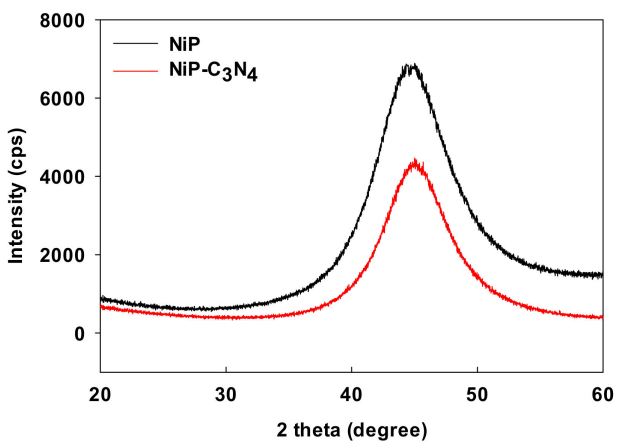

(a)

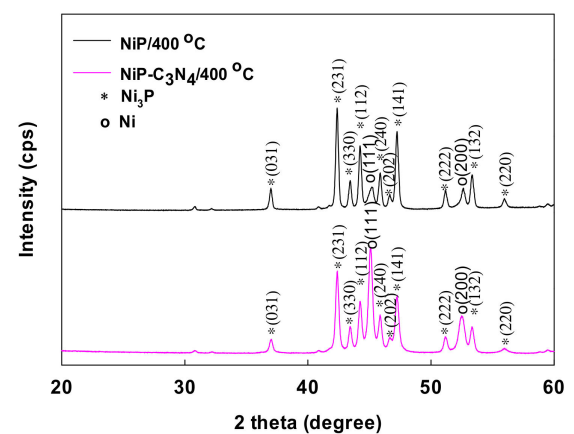

(b)

Figure 3. XRD pattern of $\mathrm{NiP}$ and $\mathrm{NiP}-\mathrm{C}_{3} \mathrm{~N}_{4}$ coatings (a) before and (b) after $\mathrm{HT}$ at $400{ }^{\circ} \mathrm{C}$ for $1 \mathrm{~h}$.

\subsection{Contact Angle Measurements}

The surface roughness of coatings, in addition to its directly related properties, e.g., hydrophilicity and hydrophobicity, are important properties to be studied. The higher the surface roughness is, the more hydrophobic and corrosion-resistant the coating will be. Figure 4 shows the water contact angles (WCAs) of the substrate (API X120 steel), the $\mathrm{NiP}$, and the $\mathrm{NiP}-\mathrm{C}_{3} \mathrm{~N}_{4}$ nanocomposite coatings before and after the $\mathrm{HT}$ at $400{ }^{\circ} \mathrm{C}$ for $1 \mathrm{~h}$.

The WCA for steel is $86^{\circ}$, i.e., less than $90^{\circ}$, indicating its hydrophilic nature. Both as-plated $\mathrm{NiP}$ and $\mathrm{NiP}-\mathrm{C}_{3} \mathrm{~N}_{4}$ coatings are hydrophobic, as their contact angles are found to be $105^{\circ}$ and $109^{\circ}$, respectively. After $\mathrm{HT}$, a decrease in the water contact angle is observed for both $\mathrm{NiP}$ and the nanocomposite coatings (Figure $4 \mathrm{~d}$,e). Because of the recrystallization of the nickel and a phase transition that led to the change in the surface chemistry and roughness of the NiP coatings, the as-plated coatings became hydrophilic after HT [27].

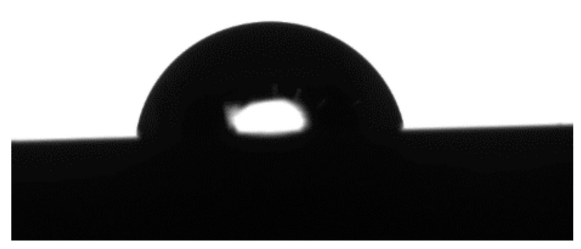

(a)

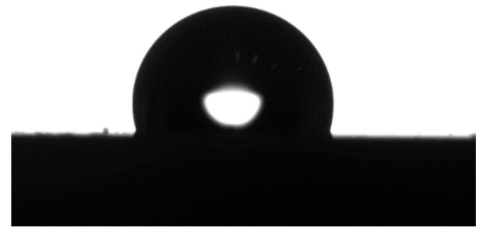

(c)

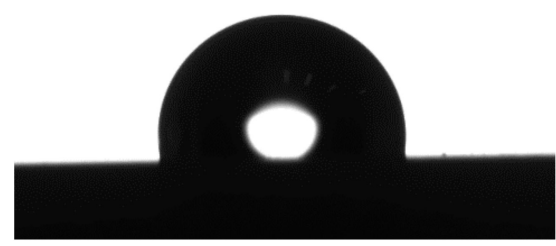

(b)

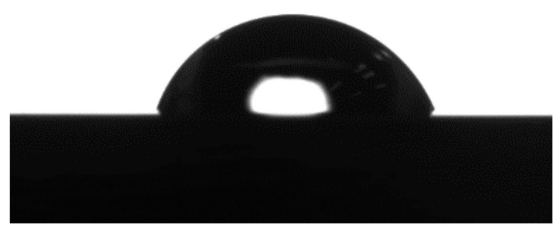

(d)

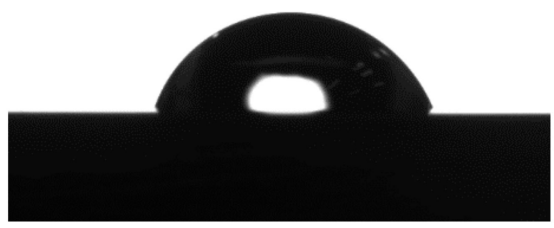

(e)

Figure 4. WCAs of coatings: (a) substrate: $\mathrm{CA}=86 \pm 1^{\circ}$; (b) as-plated NiP: $\mathrm{CA}=105 \pm 1^{\circ}$; (c) as-plated $\mathrm{NiP}-\mathrm{C}_{3} \mathrm{~N}_{4}: \mathrm{CA}=109 \pm 1^{\circ} ;(\mathbf{d})$ heat-treated NiP: $\mathrm{CA}=70.5 \pm 1^{\circ}$; and (e) heat-treated $\mathrm{NiP}-\mathrm{C}_{3} \mathrm{~N}_{4}$ : $\mathrm{CA}=72.8 \pm 1^{\circ}$. Heat treatment was done at $\mathrm{T}=400{ }^{\circ} \mathrm{C}$ for $1 \mathrm{~h}$. 


\subsection{Surface Roughness of Coatings}

The Atomic force microscopy (AFM) was used to measure the surface roughness of the NiP and $\mathrm{NiP}-\mathrm{C}_{3} \mathrm{~N}_{4}$ coatings before and after the heat treatment, as shown in Figure 5. The surface roughness of the NiP- $\mathrm{C}_{3} \mathrm{~N}_{4}$ composite coating in the presence of $\mathrm{C}_{3} \mathrm{~N}_{4}$ nanosheets in the NiP coating increased. The surface roughness of the as-plated NiP coating is $22 \mathrm{~nm}$, whereas the $\mathrm{NiP}-\mathrm{C}_{3} \mathrm{~N}_{4}$ shows a surface roughness of approximately $43 \mathrm{~nm}$. This proves the increased hydrophobicity of the NiP- $\mathrm{C}_{3} \mathrm{~N}_{4}$ coating relative to that of the $\mathrm{NiP}$ coating. It is obvious that the surface roughness of the $\mathrm{NiP}$ coating and the $\mathrm{C}_{3} \mathrm{~N}_{4}$ composite coating after the heat treatment decreased by about half of their initial values. This was attributed to the recrystallization of the coatings and the formation of the $\mathrm{Ni}_{3} \mathrm{P}$ and $\mathrm{Ni}$ crystals that are more stable and show ordered structures. Therefore, the roughness of the $\mathrm{NiP}-\mathrm{C}_{3} \mathrm{~N}_{4}$ composite coating is always higher than that of the NiP coating, even after reduction of the roughness upon the heat treatment.

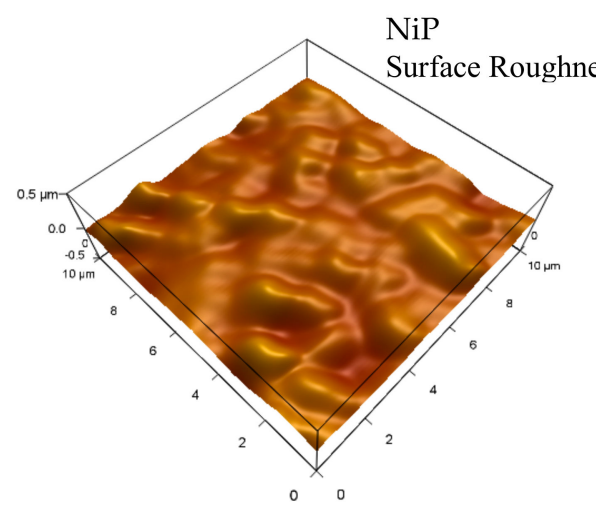

$\mathrm{NiP}$

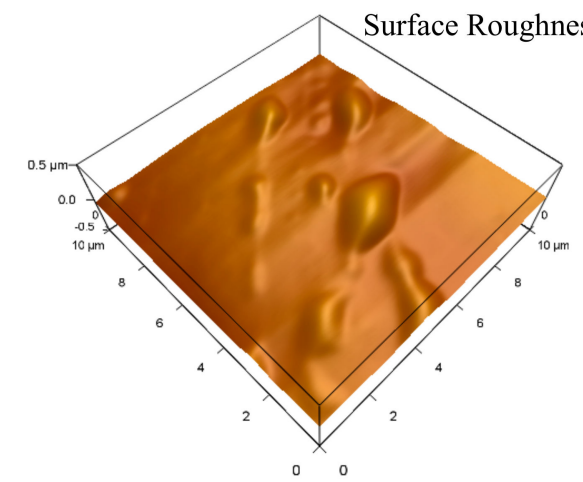

$0 \quad 0$

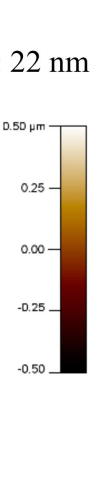

(a)

$10.96 \mathrm{~nm}$

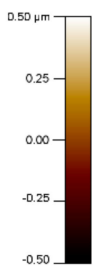

(b)

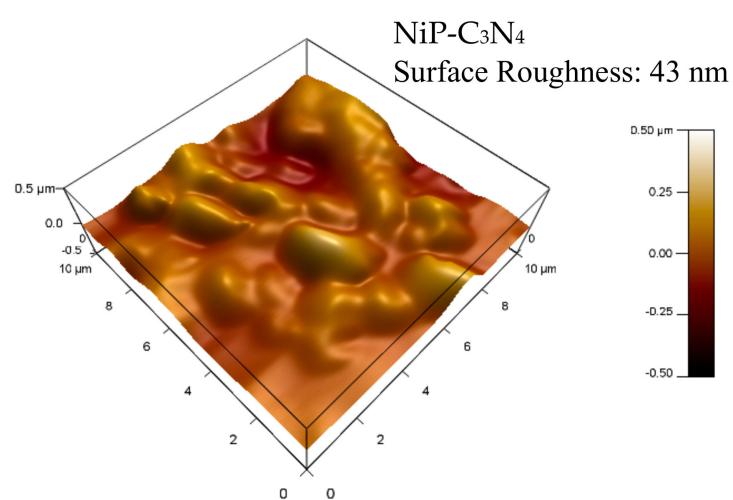

$\mathrm{NiP}-\mathrm{C}_{3} \mathrm{~N}_{4}$

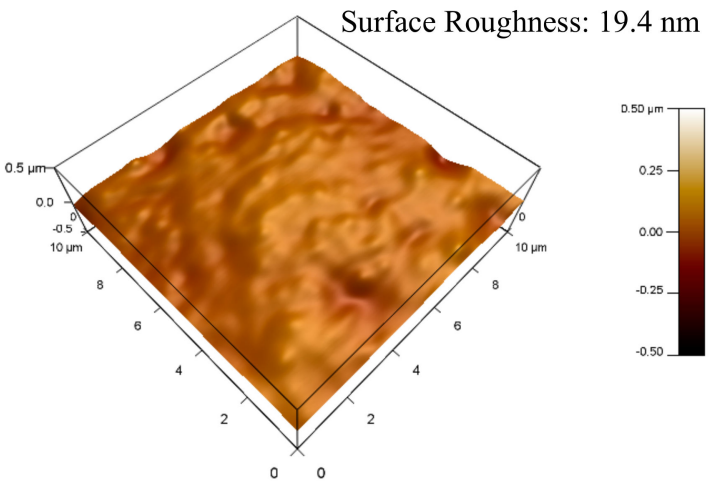

Figure 5. AFM images of electroless $\mathrm{NiP}$ and $\mathrm{NiP}-\mathrm{C}_{3} \mathrm{~N}_{4}$ nanocomposite coatings (a) before and (b) after heat treatment at $400{ }^{\circ} \mathrm{C}$ for $1 \mathrm{~h}$.

\subsection{Microhardness Measurements}

The microhardness of the NiP and NiP nanocomposite coatings before and after the heat treatment were performed in addition to that of the C-steel substrate for comparison, as illustrated in Figure 6. The measured microhardness of the substrate is approximately $166 \mathrm{HV}_{200}$. The electroless deposition of the NiP and NiP- $\mathrm{C}_{3} \mathrm{~N}_{4}$ leads to an increase in the microhardness to 406 and $645 \mathrm{HV}_{200}$, respectively. The increase in the microhardness upon the dispersion of the $\mathrm{C}_{3} \mathrm{~N}_{4}$ nanosheets is attributed to the dispersion hardening effect caused via the incorporation of the nanoparticles into the composite coatings. As reported in [28,29], the uniform distribution of the nanoparticles in the matrix could restrain the growth of the alloy grains and the plastic deformation of the coating, leading to the stabilization of the dislocation and thus increasing the microhardness. 


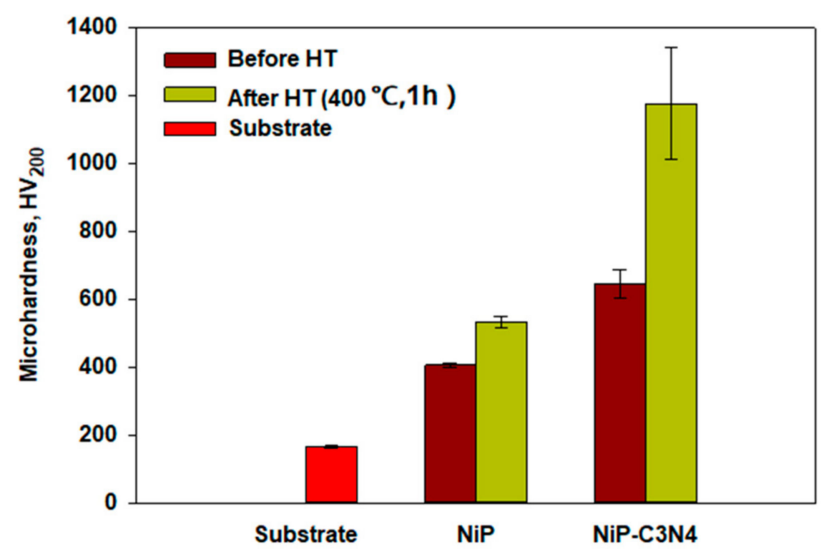

Figure 6. The microhardness of substrate, NiP coating, and NiP-C3N4 composite coating before and after heat treatment at $400{ }^{\circ} \mathrm{C}$ for $1 \mathrm{~h}$.

Upon heat treatment of $\mathrm{NiP}$ and $\mathrm{NiP}-\mathrm{C}_{3} \mathrm{~N}_{4}$ nanocomposites, the microhardness was increased significantly to 780 and $1175 \mathrm{HV}_{200}$, respectively. At that temperature $\left(400{ }^{\circ} \mathrm{C}\right)$, the $\mathrm{P}$ atoms are forced to adapt to the crystal structure of the $\mathrm{Ni}$. This adaptation resulted in the formation of a coherent relationship that leads to a distortion of the local stress field. When the Ni/P ratio gathers in a sufficient quantity, the intermetallic compound $\mathrm{Ni}_{3} \mathrm{P}$ precipitates and keeps a coherent relationship with the $\mathrm{Ni}$. The hardness of the $\mathrm{Ni}_{3} \mathrm{P}$ is gets higher when the temperature is increased, since it is formed mainly by metallic and ionic bonds, resulting in a coherent precipitation strengthening effect and an improvement of the microhardness [30]. Regarding the NiP- $\mathrm{C}_{3} \mathrm{~N}_{4}$ composite, the presence of $\mathrm{Ni}_{3} \mathrm{P}$ as the hard phase in addition to the $\mathrm{C}_{3} \mathrm{~N}_{4}$ provides an extra factor for increasing its microhardness after the heat treatment. Although the intensity of the $\mathrm{Ni}_{3} \mathrm{P}$ peaks in the $\mathrm{NiP}-\mathrm{C}_{3} \mathrm{~N}_{4}$ XRD chart is lower than the corresponding ones in the XRD chart of the $\mathrm{C}_{3} \mathrm{~N}_{4}$-free coating, the hardness is higher in the case of NiP- $\mathrm{C}_{3} \mathrm{~N}_{4}$ coating, indicating that the $\mathrm{C}_{3} \mathrm{~N}_{4}$ compensated for the decrease in the $\mathrm{Ni}_{3} \mathrm{P}$ content, which is an advantage for the new coating. In addition, it worth mentioning that the thickness of the coating in case of the $\mathrm{NiP}-\mathrm{C}_{3} \mathrm{~N}_{4}$ coating is $30 \%$ less than that in case of the $\mathrm{NiP}$ one.

\subsection{Corrosion Measurements}

\subsubsection{Electrochemical Impedance Spectroscopy (EIS)}

Figure 7a,b show the Bode and the phase angle plots of the EIS spectra that are measured at open circuit potential for the substrate with the as-plated and heat-treated $\mathrm{NiP}$, as well as $\mathrm{NiP}-\mathrm{C}_{3} \mathrm{~N}_{4}$ nanocomposite coatings immersed in a $3.5 \mathrm{wt} \% \mathrm{NaCl}$ solution at the room temperature. The larger the value of the $|Z|$ at low frequencies is, the better the corrosion protection properties of the coating will be [31]. Inspection of Figure 7a shows that the values of $|\mathrm{Z}|$ at $0.01 \mathrm{~Hz}$ for the as-plated NiP and $\mathrm{NiP}-\mathrm{C}_{3} \mathrm{~N}_{4}$ nanocomposite coatings, as well as for the heat-treated coatings, are much higher than that of the substrate, confirming the corrosion protection properties of both coatings before and after the heat treatment. The high corrosion resistance is attributed to the presence of phosphorus [32]. Generally, for a Ni-based coating, when the nickel starts to dissolve in the corrosive media, the phosphorus starts to react with water to form a film of adsorbed hypophosphite anions, preventing further hydration of the nickel. Consequently, the corrosion resistance of the coating is increased [33]. Moreover, the as-plated NiP- $\mathrm{C}_{3} \mathrm{~N}_{4}$ composite coating offers higher corrosion protection ability compared to that of the as-plated $\mathrm{NiP}$ coating despite the smaller phosphorous content in the former, as seen from the EDX results. This finding indicates the strong protective ability of the $\mathrm{C}_{3} \mathrm{~N}_{4}$ nanosheets that enhance the polarization resistance of the $\mathrm{NiP}$ nanocomposite coating in $3.5 \mathrm{wt} \% \mathrm{NaCl}$ solution to reach a maximum value of $9225 \Omega \cdot \mathrm{cm}^{2}$, as shown in Table 2. This can be attributed, as mentioned above, to the uniform distribution of $\mathrm{C}_{3} \mathrm{~N}_{4}$ nanosheets throughout the coating, which support forming a more 
compact structure, blocking the defects in the NiP coating, inhibiting the diffusion of the chloride ions to the substrate, and enhancing the corrosion resistance as shown in a similar situation in [10].

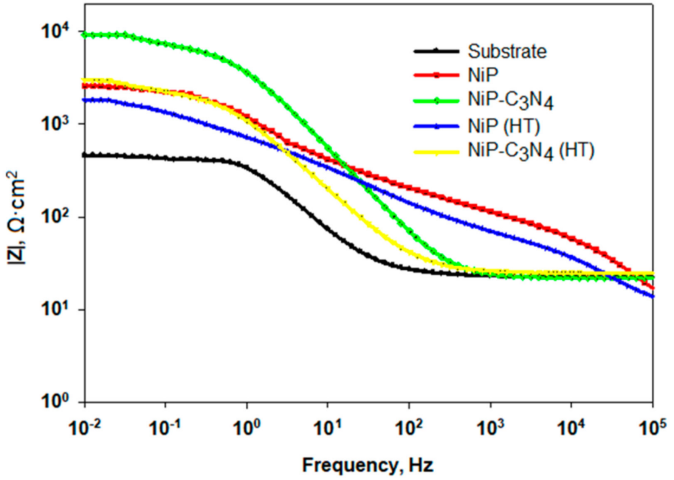

(a)

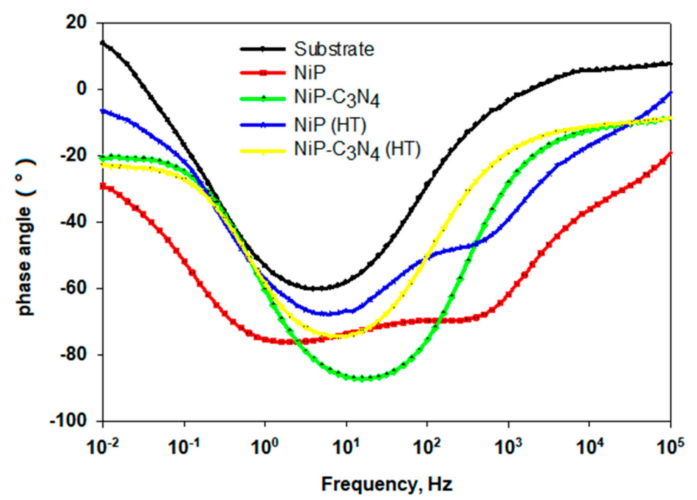

(b)

Figure 7. (a) Bode and (b) phase angle plots of the substrate, electroless as-plated NiP and $\mathrm{NiP}-\mathrm{C}_{3} \mathrm{~N}_{4}$ coatings with and without heat treatment at $400{ }^{\circ} \mathrm{C}$ for $1 \mathrm{~h}$ in $3.5 \mathrm{wt} \% \mathrm{NaCl}$ solution at room temperature.

In addition, in Figure $7 \mathrm{a}$, the Bode plots of the as-plated $\mathrm{NiP}$ and $\mathrm{NiP}-\mathrm{C}_{3} \mathrm{~N}_{4}$ nanocomposite coatings display different shapes in the recorded frequency regions, illustrating that different fundamental processes occur on their surfaces. This behavior is more conspicuous in the plots of the phase angle versus frequency (Figure $7 \mathrm{~b}$ ). The Bode and phase angle plots for the NiP coating show two broad peaks at the analyzed frequency range, which confirms two-time constants behavior. The first relaxation process is related to the coating layer that can be checked at the higher and intermediate frequencies, whereas the second relaxation process is observed at the lower frequencies and represents the electrochemical behavior at the interface of the substrate and the coating [34]. The Bode and phase angle plots for the $\mathrm{NiP}-\mathrm{C}_{3} \mathrm{~N}_{4}$ nanocomposite coating show one time-constant behavior, as shown in Figure $7 \mathrm{~b}$.

The equivalent circuits that are used in analyzing the EIS measured spectra for both the as-plated $\mathrm{NiP}$ and $\mathrm{NiP}-\mathrm{C}_{3} \mathrm{~N}_{4}$ coatings with and without heat treatment are depicted in Figure 8a,b, respectively. The circuit in Figure 8a includes the solution resistance $\left(R_{\mathrm{s}}\right)$, the high frequency time constant $\left(R_{1} \cdot \mathrm{CPE}_{1}\right)$, and the low frequency time constant $\left(R_{2} \cdot \mathrm{CPE}_{2}\right)$. The high frequency time constant $\left(R_{1} \cdot \mathrm{CPE}_{1}\right)$ corresponds to the areas covered with the coating and can be represented by the coating admittance $\left(\mathrm{CPE}_{\text {coat }}\right)$ and the pore resistance $\left(R_{\mathrm{po}}\right)$. The low frequency time constant is assigned to the polarization resistance $\left(R_{\mathrm{p}}\right)$ and the admittance associated with the double layer capacitance $\left(\mathrm{CPE}_{\mathrm{dl}}\right)$. The equivalent circuit in Figure $8 \mathrm{~b}$ consists of the solution resistance, the double layer capacity, the polarization resistance, and the Warburg diffusion element $(W)$. The electrochemical parameters derived from fitting the measured data using the equivalent circuits are listed in Table 2. As is clearly shown in this table, the increased polarization resistance is related to the presence of the $\mathrm{C}_{3} \mathrm{~N}_{4}$ nanosheets. Moreover, the NiP- $\mathrm{C}_{3} \mathrm{~N}_{4}$ composite coating has the lowest double layer capacitance $\left(39 \mu \mathrm{F} \cdot \mathrm{cm}^{-2} \cdot \mathrm{s}^{-n}\right)$ and the higher value of $n$ (0.9) compared to those of the NiP coating. Taken together, these characteristics lead to the superior protection efficiency of the composite coating reaching as high as $95 \%$. The protection efficiency of the NiP coating is approximately $70.9 \%$, which is less than that of the composite due to its porosity, which allows the aggressive chloride ions to diffuse into the substrate.

After heat treatment, the polarization resistances of both heat-treated $\mathrm{NiP}$ and $\mathrm{NiP}-\mathrm{C}_{3} \mathrm{~N}_{4}$ are decreased compared to the corresponding polarization resistances for the as-plated coatings, but are still much greater than that of the substrate. The protective ability of the as-plated $\mathrm{NiP}$ and $\mathrm{NiP}-\mathrm{C}_{3} \mathrm{~N}_{4}$ composite coatings decreases after the heat treatment by approximately $11 \%$ and $9.5 \%$, respectively, as shown in Table 2. However, the protection efficiency of the heat-treated NiP- $\mathrm{C}_{3} \mathrm{~N}_{4}$ composite 
coating is still higher by $13 \%$ and $4 \%$ than that of the heat-treated and as-plated NiP coatings, respectively. The decrease in the corrosion protection observed for both heat-treated coatings is due to the formation of nickel phosphide $\left(\mathrm{Ni}_{3} \mathrm{P}\right)$ that reduces the phosphorus content of the remaining material and transforms the coating from amorphous to crystalline. Previous work has shown that the amorphous alloys have better corrosion resistance than their corresponding crystalline due to the formation of glassy films that passivate their surfaces [33].

The $n$ values for both $\mathrm{NiP}$ and $\mathrm{NiP}-\mathrm{C}_{3} \mathrm{~N}_{4}$ coatings before and after the heat treatment lie between 0.6 and 0.9 (Table 2). This indicates that the system is far from the ideal capacitive behavior. The deviation from the ideal capacitive behavior is related to the inhomogeneity of the coating surface attributed to the roughness and surface porosity of the coating. According to the obtained values of the $\mathrm{CPE}_{\mathrm{dl}}$ presented in Table 2, the $\mathrm{NiP}-\mathrm{C}_{3} \mathrm{~N}_{4}$ composite coating before and after the heat treatment has the most homogeneous surface with a lower porosity compared to that of the NiP coating. Consequently, a dense $\mathrm{NiP}-\mathrm{C}_{3} \mathrm{~N}_{4}$ composite coating is formed on the substrate that is slightly affected by high temperatures.

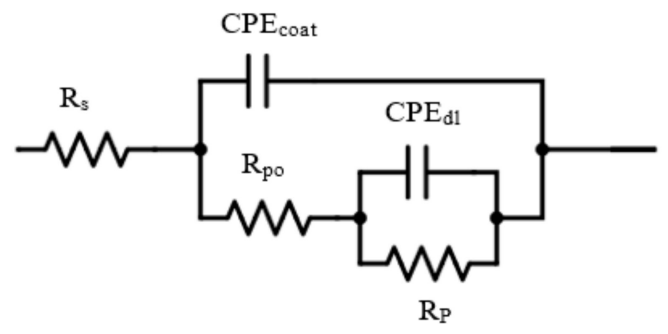

(a)

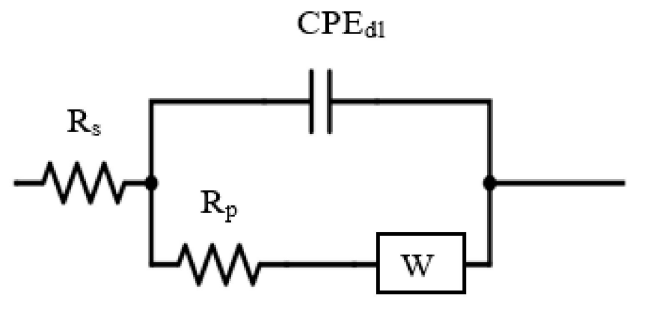

(b)

Figure 8. Equivalent electric circuits for (a) as-plated and heat-treated NiP coating and (b) as-plated and heat-treated $\mathrm{NiP}-\mathrm{C}_{3} \mathrm{~N}_{4}$ composite coating, in $3.5 \mathrm{wt} \% \mathrm{NaCl}$ solution.

Table 2. Electrochemical parameters obtained by fitting the measured data shown in Figure 7 using the equivalent circuits shown in Figure 8 of the substrate, $\mathrm{NiP}$, and $\mathrm{NiP}-\mathrm{C}_{3} \mathrm{~N}_{4}$ composite coatings with and without heat treatment.

\begin{tabular}{|c|c|c|c|c|c|c|c|c|}
\hline $\begin{array}{l}\text { Type of } \\
\text { Coating }\end{array}$ & $\begin{array}{c}R_{\mathrm{s}} \\
\left(\Omega \cdot \mathrm{cm}^{2}\right)\end{array}$ & $\begin{array}{c}R_{\text {po }} \\
\left(\Omega \cdot \mathrm{cm}^{2}\right)\end{array}$ & $\begin{array}{c}\mathrm{CPE}_{\text {coat }} \\
\left(\mu \mathrm{F} \cdot \mathrm{cm}^{-2} \cdot \mathrm{s}^{-n}\right)\end{array}$ & $\begin{array}{c}R_{\mathrm{p}} \\
\left(\Omega \cdot \mathrm{cm}^{2}\right)\end{array}$ & $\begin{array}{c}\mathrm{CPE}_{\mathrm{d} 1} \\
\left(\mu \mathrm{F} \cdot \mathrm{cm}^{-2} \cdot \mathrm{s}^{-n}\right)\end{array}$ & $\begin{array}{c}W \\
\left(S \cdot s^{1 / 2}\right)\end{array}$ & $n$ & $\begin{array}{l}I E \\
(\%)\end{array}$ \\
\hline Substrate & 22.4 & - & - & 445 & 526.5 & - & - & - \\
\hline $\mathrm{NiP}$ & 17.6 & 167.50 & 28.4 & 2336 & 294 & - & 0.7 & 81 \\
\hline $\mathrm{NiP}-\mathrm{C}_{3} \mathrm{~N}_{4}$ & 21.9 & - & - & 9225 & 39 & $1.021 \times 10^{-3}$ & 0.9 & 95 \\
\hline $\mathrm{NiP}(\mathrm{HT})$ & 15.6 & 16.9 & 35 & 1597 & 324.6 & - & 0.65 & 72 \\
\hline $\mathrm{NiP}-\mathrm{C}_{3} \mathrm{~N}_{4}(\mathrm{HT})$ & 23.4 & - & - & 2990 & 170.00 & $3.879 \times 10^{-3}$ & 0.8 & 85 \\
\hline
\end{tabular}

\subsubsection{Tafel Analysis}

The potentiodynamic polarization curves for the substrate and electroless $\mathrm{NiP}$, as well as $\mathrm{NiP}-\mathrm{C}_{3} \mathrm{~N}_{4}$ coatings before and after the heat treatment in $3.5 \mathrm{wt} \% \mathrm{NaCl}$ solution at room temperature, are shown in Figure 9. The electrochemical parameters (corrosion potential $\left(E_{\text {corr }}\right)$, corrosion current density $\left(i_{\text {corr }}\right)$, cathodic and anodic Tafel slopes, and corrosion inhibition efficiency IE) are presented in Table 3. $E_{\text {corr }}$ of the NiP coating $(-542 \mathrm{mV})$ is shifted significantly in the anodic direction compared to the C-steel, and that of the NiP- $\mathrm{C}_{3} \mathrm{~N}_{4}$ is even more anodically shifted to $-309 \mathrm{mV}$. $i_{\text {corr }}$ of the substrate, $\mathrm{NiP}$, and NiP-C${ }_{3} \mathrm{~N}_{4}$ composite coatings are $21.4,6.9$, and $1.8 \mu \mathrm{A} \cdot \mathrm{cm}^{-2}$, respectively. The decrease in the $i_{\text {corr }}$ of the NiP- $\mathrm{C}_{3} \mathrm{~N}_{4}$ composite coating compared to that of the $\mathrm{NiP}$ coating reveals a better corrosion resistance for the new composite coating. After heat treatment, $E_{\text {corr }}$ of the NiP and the $\mathrm{NiP}-\mathrm{C}_{3} \mathrm{~N}_{4}$ composite coatings are shifted in the cathodic direction. In addition, the $i_{\text {corr }}$ values of the NiP and $\mathrm{NiP}-\mathrm{C}_{3} \mathrm{~N}_{4}$ coatings are slightly increased compared to those before the heat treatment. This is due to the formation of crystalline $\mathrm{Ni}_{3} \mathrm{P}$. Consequently, an increase in $i_{\text {corr }}$ results in a decrease in the $I E$ to 
$60 \%$ and $82 \%$ for the heat-treated $\mathrm{NiP}$ and $\mathrm{NiP}-\mathrm{C}_{3} \mathrm{~N}_{4}$ coatings, respectively. It is worth mentioning that the IE of the heat-treated NiP- $\mathrm{C}_{3} \mathrm{~N}_{4}$ composite coating is still higher than those of the NiP coating before and after the heat treatment. This is attributed to the existence of $\mathrm{C}_{3} \mathrm{~N}_{4}$, which enhances the corrosion resistance by forming a more compact composite structure via uniform dispersion into the NiP matrix (confirmed by EDX mapping) and blocking the defects in the NiP coating [29].

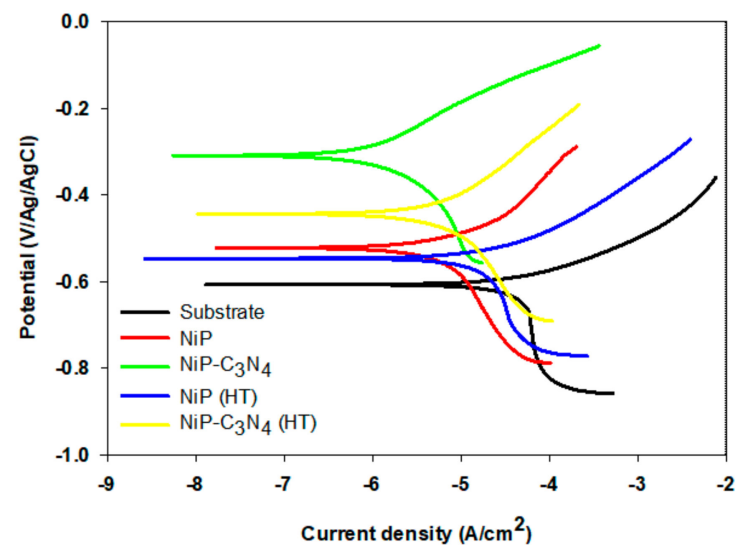

Figure 9. Polarization curves for the substrate, electroless $\mathrm{NiP}$, and $\mathrm{NiP}-\mathrm{C}_{3} \mathrm{~N}_{4}$ deposits, with and without heat treatment in $3.5 \mathrm{wt} \% \mathrm{NaCl}$ solution at room temperature. The scan rate is $0.167 \mathrm{mV} \cdot \mathrm{s}^{-1}$.

Table 3. Electrochemical parameters of different coatings before and after heat treatment derived from polarization curves shown in Figure 9.

\begin{tabular}{|c|c|c|c|c|c|c|}
\hline $\begin{array}{l}\text { Type of } \\
\text { Coating }\end{array}$ & $\begin{array}{l}E_{\text {corr }} \\
(\mathrm{mV})\end{array}$ & $\begin{array}{c}i_{\text {corr }} \\
\left(\mu \mathrm{A} \cdot \mathrm{cm}^{-2}\right)\end{array}$ & $\begin{array}{c}b_{\mathrm{a}} \\
\text { (V/decade) }\end{array}$ & $\begin{array}{c}b_{\mathrm{c}} \\
\text { (V/decade) }\end{array}$ & $\begin{array}{l}\text { Corrosion Rate } \\
\text { (mpy) }\end{array}$ & $\begin{array}{l}I E \\
(\%)\end{array}$ \\
\hline Substrate & -607 & 21.4 & 0.1 & 0.17 & 3.55 & - \\
\hline $\mathrm{NiP}$ & -542 & 6.9 & 0.09 & 0.15 & 2.91 & 71.4 \\
\hline $\mathrm{NiP}-\mathrm{C}_{3} \mathrm{~N}_{4}$ & -309 & 1.8 & 0.15 & 0.12 & 1.4 & 91.5 \\
\hline $\mathrm{NiP}(\mathrm{HT})$ & -546 & 8.4 & 0.04 & 0.11 & 6.5 & 60.4 \\
\hline $\mathrm{NiP}-\mathrm{C}_{3} \mathrm{~N}_{4}(\mathrm{HT})$ & -444 & 3.8 & 0.11 & 0.12 & 2.26 & 82 \\
\hline
\end{tabular}

\section{Conclusions}

The electroless deposition of the NiP- $\mathrm{C}_{3} \mathrm{~N}_{4}$ nanocomposite coating is successfully achieved by sonicating the $\mathrm{C}_{3} \mathrm{~N}_{4}$ nanosheets in the electroless NiP bath under the same conditions used for NiP electroless deposition. The morphology, structure, roughness, wettability, hardness, and corrosion resistance of the novel electroless $\mathrm{NiP}-\mathrm{C}_{3} \mathrm{~N}_{4}$ nanocomposite coating in comparison with the conventional NiP coating before and after heat treatment show superior properties of the new nanocomposite compared to the NiP alloy. The structure of the as-deposited NiP coating is amorphous, whereas that of the as-deposited $\mathrm{NiP}-\mathrm{C}_{3} \mathrm{~N}_{4}$ composite coating is crystalline-amorphous. The microstructure of the NiP coating is affected by the existence of the $\mathrm{C}_{3} \mathrm{~N}_{4}$ nanosheets, which are uniformly spread within the NiP matrix. The existence of the $\mathrm{C}_{3} \mathrm{~N}_{4}$ nanosheets and the heat treatment significantly enhances the microhardness of the NiP coating. The orderly presence of the $\mathrm{C}_{3} \mathrm{~N}_{4}$ nanosheets in the coating led to the increase in the protection efficiency of the as-plated composite coating in a $3.5 \mathrm{wt} \% \mathrm{NaCl}$ solution to $95 \%$ based on EIS results. After heat treatment, the formation of the crystalline $\mathrm{Ni}_{3} \mathrm{P}$ phase slightly decreased the corrosion resistance of both the $\mathrm{NiP}$ and $\mathrm{NiP}-\mathrm{C}_{3} \mathrm{~N}_{4}$ nanocomposite coatings. However, the $\mathrm{NiP}-\mathrm{C}_{3} \mathrm{~N}_{4}$ nanocomposite still shows a corrosion protection efficiency that is higher than that of the NiP even before heat treatment.

Acknowledgments: This work was supported by the NPRP grant \# NPRP8-1212-2-499 from the Qatar National Research Fund (a member of Qatar Foundation). The statements made herein are solely the responsibility of the authors. 
Author Contributions: Eman M. Fayyad, Aboubakr M. Abdullah and Mohammad K. Hassan conceived and designed the experiments; Eman M. Fayyad performed the experiments; Eman M. Fayyad and Aboubakr M. Abdullah analyzed the data; Chuhong Wang, George Jarjoura and Zoheir Farhat contributed materials and revised the paper; Eman M. Fayyad wrote the first draft of the manuscript and Aboubakr M. Abdullah, Mohammad K. Hassan and Adel M. Mohamed revised the paper.

Conflicts of Interest: The authors declare no conflict of interest.

\section{References}

1. HariKrishnan, K.; John, S.; Srinivasan, K.N.; Praveen, J.; Ganesan, M.; Kavimani, P.M. An overall aspect of electroless Ni-P depositions-A review article. Metall. Mater. Trans. A 2006, 37, 1917-1926. [CrossRef]

2. Balaraju, J.N.; Narayana, T.S.N.S.; Seshadri, S.K. Electroless Ni-P composite coatings. J. Appl. Electrochem. 2003, 33, 807-816. [CrossRef]

3. Agarwala, R.C.; Agarwala, V.; Sharma, R. Electroless Ni-P based nano coating technology-A review. Synth. React. Inorg. Met.-Org. Chem. 2006, 36, 493-515. [CrossRef]

4. Makkar, P.; Agarwala, R.C.; Agarwala, V. Studies on electroless coatings at IIT Roorkee-A brief review. Mater. Sci. Forum 2013, 33, 275-288. [CrossRef]

5. Sahoo, P.; Das, S.K. Tribology of electroless nickel coatings-A review. Mater. Des. 2011, 32, 1760-1775. [CrossRef]

6. Sharma, S.B.; Agarwala, R.C.; Agarwala, V.; Ray, S. Dry sliding wear and friction behavior of $\mathrm{Ni}-\mathrm{P}-\mathrm{ZrO}_{2}-\mathrm{Al}_{2} \mathrm{O}_{3}$ composite electroless coatings on aluminium. Mater. Manuf. Processes 2002, 17, $637-649$. [CrossRef]

7. Srinivasan, K.N.; Thangavelu, P. Electroless deposition of Ni-P composite coatings containing kaolin nanoparticles. Trans. Inst. Met. Finish. 2012, 90, 105-112. [CrossRef]

8. Hu, J.; Fang, L.; Zhong, P. Effect of Reinforcement Particle Size on Fabrication and Properties of Composite Coatings. Mater. Manuf. Processes 2013, 28, 1294-1300. [CrossRef]

9. Sharma, A.; Singh, A.K. Electroless Ni-P and Ni-P- $\mathrm{Al}_{2} \mathrm{O}_{3}$ Nanocomposite Coatings and Their Corrosion and Wear Resistance. J. Mater. Eng. Perform. 2013, 22, 176-183. [CrossRef]

10. Zhou, H.-M.; Jia, Y.; Li, J.; Yao, S.-H. Corrosion and wear resistance behaviors of electroless Ni-Cu-P-TiN composite coating. Rare Met. 2016, 1-6. [CrossRef]

11. Rezagholizadeh, M.; Ghaderi, M.; Heidary, A.; Vaghefi, S.M.M. Electroless Ni-P/Ni-B-B ${ }_{4}$ C duplex composite coatings for improving the corrosion and tribological behavior of $\mathrm{Ck}_{45}$ steel. Prot. Met. Phys. Chem. Surf. 2015, 51, 234-239. [CrossRef]

12. Yang, Y.; Chen, W.; Zhou, C.; Xu, H.; Gao, W. Fabrication and characterization of electroless $\mathrm{Ni}^{-\mathrm{P}-\mathrm{ZrO}} 2$ nano-composite coatings. Appl. Nanosci. 2011, 1, 19-26. [CrossRef]

13. Soleimani, R.; Mahboubi, F.; Kazemi, M.; Arman, S.Y. Corrosion and tribological behaviour of electroless $\mathrm{Ni}-\mathrm{P} /$ nano-SiC composite coating on aluminium 6061. Surf. Eng. 2015, 31, 714-721. [CrossRef]

14. Novakovic, J.; Vassiliou, P.; Samara, K.; Argyropoulos, T. Electroless Ni-P-TiO 2 composite coatings: Their production and properties. Surf. Coat. Technol. 2004, 201, 895-901. [CrossRef]

15. Xu, S.; Hu, X.; Yang, Y.; Chen, Z.; Chan, Y.C. Effect of carbon nanotubes and their dispersion on electroless Ni-P under bump metallization for lead-free solder interconnection. J. Mater. Sci. Mater. Electron. 2014, 25, 2682-2691. [CrossRef]

16. Liu, S.; Bian, X.; Liu, J.; Yang, C.; Zhao, X.; Fan, J.; Zhang, K.; Bai, Y.; Xu, H.; Liu, Y. Structure and properties of Ni-P-graphite $\left(\mathrm{C}_{\mathrm{g}}\right)-\mathrm{TiO}_{2}$ composite coating. Surf. Eng. 2015, 31, 420-426. [CrossRef]

17. Ashassi-Sorkhabi, H.; Es'haghi, M. Corrosion resistance enhancement of electroless Ni-P coating by incorporation of ultrasonically dispersed diamond nanoparticles. Corros. Sci. 2013, 77, 185-193. [CrossRef]

18. Liu, A.Y.; Cohen, M.L. Prediction of new low compressibility solids. Science 1989, 245, 841. [CrossRef] [PubMed]

19. Liu, A.Y.; Cohen, M.L. Structural properties and electronic structure of low-compressibility materials: $\beta-\mathrm{Si}_{3} \mathrm{~N}_{4}$ and hypothetical $\beta-\mathrm{C}_{3} \mathrm{~N}_{4}$. Phys. Rev. B 1990, 41, 10727. [CrossRef]

20. Zhang, Z.; Guo, H.; Xu, Y.; Zhang, W.; Fan, X. Corrosion resistance studies on $\alpha-C_{3} N_{4}$ thin films deposited on pure iron by plasma-enhanced chemical vapor deposition. J. Mater. Sci. Lett. 1999, 18, 685-687. [CrossRef]

21. Xu, H.; Yanga, Z.; Li, M.K.; Shi, Y.L.; Huang, Y.; Li, H.L. Synthesis and properties of electroless Ni-P-nanometer diamond composite coatings. Surf. Coat. Technol. 2005, 191, 161-165. [CrossRef] 
22. Al-Kandari, H.; Abdullah, A.M.; Ahmad, Y.H.; Al-Kandari, S.; AlQaradawi, S.Y.; Mohamed, A.M. An efficient eco advanced oxidation process for phenol mineralization using a 2D/3D nanocomposite photocatalyst and visible light irradiations. Sci. Rep. 2017, 7, 9898. [CrossRef] [PubMed]

23. Sudagar, J.; Lian, J.; Sha, W. Electroless nickel, alloy, composite and nano coatings-A critical review. J. Alloy. Compd. 2013, 571, 183-204. [CrossRef]

24. Rajabalizadeh, Z.; Seifzadeh, D. The effect of copper ion on microstructure, plating rate and anticorrosive performance of electroless Ni-P coating on AZ61 magnesium alloy. Prot. Met. Phys. Chem. Surf. 2014, 50, 516-523. [CrossRef]

25. Afroukhteh, S.; Dehghaniann, C.; Emamy, M. Preparation of electroless Ni-P composite coatings containing nano-scattered alumina in presence of polymeric surfactant. Prog. Nat. Sci. Mater. Int. 2012, 22, 318-325. [CrossRef]

26. Zou, Y.; Cheng, Y.; Cheng, L.; Liu, W. Effect of Tin Addition on the Properties of Electroless Ni-P-Sn Ternary Deposits. Mater. Trans. 2010, 51, 277-281. [CrossRef]

27. Karthikeyan, S.; Vijayaraghavan, L. Investigation of the surface properties of heat-treated electroless Ni-P coating. Trans. IMF 2016, 94, 265-273. [CrossRef]

28. Balaraju, J.N.; Kalavati; Rajam, K.S. Influence of particle size on the microstructure, hardness and corrosion resistance of electroless Ni-P- $\mathrm{Al}_{2} \mathrm{O}_{3}$ composite coatings. Surf. Coat. Technol. 2006, 200, 3933-3941. [CrossRef]

29. Aal, A.A.; El-Sheikh, S.M.; Ahmed, Y.M.Z. Electrodeposited composite coatings of Ni-W-P with nano-sized rod and spherical-shaped SiC particles. Mater. Res. Bull. 2009, 44, 151-159. [CrossRef]

30. Liu, B.; Liu, L.; Liu, X. Effects of carbon nanotubes on hardness and internal stress in Ni-P coatings. Surf. Eng. 2013, 29, 507-510. [CrossRef]

31. Sharma, S.K. Green Corrosion Chemistry and Engineering; Wiley-VCH: Weinheim, Germany, 2012.

32. MafiIman, R.; Dehghanian, C. Studying the effect of the addition of TiN nanoparticles to NiP electroless coatings. Appl. Surf. Sci. 2011, 258, 1876-1880.

33. Hu, J.; Fang, L.; Liao, X.-L.; Shi, L.-T. Influences of different reinforcement particles on performances of electroless composites. Surf. Eng. 2017, 33, 362-386. [CrossRef]

34. Balaraju, J.N.; EzhilSelvi, V.; Rajam, K.S. Elactrochemical behavior of low phosphorous electroless Ni-P-Si $3 \mathrm{~N}_{4}$ composite coatings. Mater. Chem. Phys. 2010, 120, 546-551. [CrossRef] 